\title{
(RE)CONSTRUCCIÓN DEL PASADO RECIENTE: MEMORIA Y ESCRITURA EN URUGUAY. EL CASO DE OBLIVION DE EDDA FABBRI
}

(Re)construction of a Recent Past: Memory and Writing in Uruguay: The Case of Oblivion by Edda Fabbri

\author{
Viviana PÉREZ HerRera \\ Universidad de BARCELONA / Universidad CATÓLICA DEL NoRTE (CHILE) \\ vv.herrera.87@gmail.com
}

RECIBIDO: 10 DE MARZO DE 2018

ACEPTADO: 3 DE MAYO DE 2019

RESUMEN: La literatura testimonial que surge en América Latina a fines de los años noventa tiene como temática principal el rescate de la memoria centrada en la violencia de Estado de las dictaduras militares de las décadas anteriores. En el caso uruguayo, la escritura testimonial de ex presas políticas dará cuenta de la silenciosa y tormentosa vida tras las rejas, y de las necesarias relaciones de compañerismo que posibilitan resistir: un ejemplo de lo anterior es Oblivion de Edda Fabbri, testimonio galardonado por el Premio Literario Casa de las Américas en 2007. El propósito de este artículo es identificar el modo en que en Oblivion la voz testimonial de una ex presa política militante del Movimiento de Liberación Nacional Tupamaros intenta reconstruir la memoria de su pasado carcelario que se dibuja en una serie de imágenes fragmentadas guardadas en el cuerpo. La escritura, aunque insuficiente, se establecerá como el medio por el que la hablante hará presente el dolor, no con la intención de historiar, sino para dejar una huella del pasado violento que permita, a la vez, buscar el perdón. La paradoja entre memoria y olvido que atraviesa al testimonio jugará un importante rol en dicha búsqueda. El análisis se centrará en tres núcleos de reflexión: el vínculo entre el tiempo y la memoria, la relación entre dolor, cuerpo y escritura, y la idea de olvido como perdón.

PALABRAS CLAVE: escritura testimonial, memoria, tiempo, cuerpo, olvido, perdón.

ABSTRACT: The testimonial literature that emerges during the late 1990s in Latin America has as a main theme the rescue of the memory centered on State violence during the military dictatorships that occurred in previous decades. In the Uruguayan case, the testimonial writing from former female political prisoners will account for the silent and stormy life behind bars, and for the necessary companion relationships that make possible to resist. One example of this is Oblivion by Edda Fabbri, a testimonial novel awarded with the Casa de las Américas Prize in 2007. The purpose of this article is to identify how, in Oblivion, the testimonial voice of a former political prisoner who was a member of the Tupamaros National Liberation Movement tries to reconstruct the memory of her past as a prisoner through a series of fragmented images kept in her body. The writing, although insufficient, will be established as the means by which the speaker will express the pain, with no intention of focusing on facts, but with the purpose of leaving a trace of a violent past, which, in turn, allows to seek forgiveness. The paradox between memory and oblivion constantly present in the testimony plays a major role in such a search. The analysis will center its attention on three major themes for discussion: the link between time and memory, the connection between pain, body and writing, and the idea of oblivion as forgiveness.

KEywords: Testimonial Writing, Memory, Time, Body, Oblivion, Forgiveness.

Pérez Herrera, Viviana.

“(Re)construcción del pasado reciente: memoria y escritura en Uruguay. El caso de Oblivion de Edda Fabbri”.

Kamchatka. Revista de análisis cultural 13 (Junio 2019): 487-507.

DOI: 10.7203/KAM.13.13126 ISSN: 2340-1869 


\section{INTRODUCCIÓN 1}

La literatura testimonial de ex presas políticas uruguayas es un campo de reciente indagación que ha posibilitado el conocimiento de la vida carcelaria de mujeres y las relaciones de compañerismo y resistencia que se establecieron entre ellas y contra sus opresores. Es el caso específico de escrituras que nacen de las experiencias carcelarias vividas en el Penal de Punta de Rieles y Paso de los Toros, lugares de prisión exclusivos para mujeres participantes de movimientos de resistencia, principalmente, del Movimiento de Liberación Nacional Tupamaros.

Procesos judiciales y políticos acontecidos a finales de la década de los noventa no solo en Uruguay, sino también en el resto de los países del Cono Sur, propician un escenario de auge de la literatura testimonial. Así, sucesos como la detención del dictador chileno Augusto Pinochet en Londres en 1998; los encarcelamientos por secuestros de niños a miembros de las Juntas Militares de Argentina; la reapertura del caso Berríos en Chile; la creación de la Comisión por la Paz y apertura de la investigación sobre los desaparecidos en Uruguay; y el auge de gobiernos de izquierda (Alzugarat, 2007), contribuyen a despertar en la población la preocupación por recuperar la memoria del pasado inmediato, y por la valoración y defensa de los derechos humanos afectados por la violencia ejercida por el Estado en los procesos dictatoriales recientes.

Además de los diversos acontecimientos políticos y judiciales desarrollados en Uruguay, en 1997 se lleva a cabo una reunión de alrededor de trescientas ex presas políticas del Penal de Punta de Rieles que busca realizar "un trabajo en conjunto de reconstrucción de la memoria de los años de dictadura y del pasaje por la prisión” (Alzugarat, 2007: 198). Esta instancia impulsa a un grupo numeroso, no solo de mujeres militantes tupamaras, sino también de familiares y de otros sobrevivientes de la violencia de Estado, a narrar su experiencia carcelaria silenciada por varios años. De este encuentro y de los próximos que tendrán lugar, nace el Taller de Género y Memoria de ex presas políticas, taller que da vida a los volúmenes de Memorias para armar, obras que recopilan una serie de relatos que dan cuenta del periodo de dictadura y de las huellas que este ha dejado.

La experiencia de escritura grupal que se establece a partir del Taller de Género y Memoria funda diversas instancias de encuentro que permiten a Edda Fabbri escribir su obra testimonial Oblivion:

Con posterioridad se formó otro grupo en el cual participé, que dio una serie de charlas de dos generaciones: la de los que habíamos estado presos y los más jóvenes, que pudieran ser nuestros hijos. De esa experiencia, que fue muy rica, volví a mi casa y comencé a escribir, sin la idea de que realizaría un libro, sino porque sentía la necesidad de comunicar lo que a mí me quedaba y rescataba en la memoria a partir de esas reuniones. En algún momento que no sé definir se transformó en un libro (Hormilla, 2013).

Oblivion $^{2}$ es un testimonio que narra las huellas que deja un periodo de trece años en prisión (1972-1985) que vive una ex presa política, militante del Movimiento de Liberación Nacional

\footnotetext{
${ }^{1}$ La autora agradece por su apoyo a CONICYT PFCHA/ Doctorado Becas Chile - 72180158.

2 Para el presente artículo se analizó la segunda edición publicada en 2012 por la editorial Letraeñe.
} 
Tupamaros (MLN), en la Prisión de Punta de Rieles. Es un texto que destaca por haber sido galardonado en el Premio Literario Casa de las Américas de 2007 en la categoría de "literatura testimonial" cuyo jurado, compuesto por el chileno Manuel Cabieses, el colombiano José Castaño Hoyos y la cubana Daysi Rubiera, premia esta obra por poseer "gran valor testimonial y literario que demuestra no solo un eficiente uso de las técnicas narrativas, sino además una valiosa sensibilidad que enriquece y sincera el relato"3.

El propósito de este artículo es identificar el modo en que la voz narrativa de la obra testimonial Oblivion de Edda Fabbri intenta reconstruir, desde su presente, la memoria de un pasado carcelario que se dibuja en una serie de imágenes fragmentadas guardadas en el cuerpo. La escritura, aunque insuficiente, se establecerá como el medio por el que la hablante hará presente el dolor, no con la intención de historiar, sino con la finalidad de dejar una huella, una evidencia del pasado violento que permita, a la vez, buscar el perdón. La paradoja entre memoria y olvido que atraviesa al testimonio jugará un importante rol en dicha búsqueda. El análisis se centrará en tres núcleos de reflexión: el vínculo entre el tiempo y la memoria, la relación entre dolor, cuerpo y escritura, y la idea de olvido como perdón.

Oblivion se escribe veinte años después del periodo carcelario que vive Fabbri y una serie de compañeras militantes tupamaras. La distancia temporal que se establece entre ese pasado y el presente desde el que se recuerda, permite abordar los sucesos desde "[u]na catarsis más serena y reflexiva [que] pone mayor acento en realzar el valor de los sentimientos, la solidaridad y la vida familiar, especialmente en los testimonios femeninos" (Alzugarat, 2007: 199-200). Dicha característica diferencia a la literatura testimonial de este periodo de los testimonios existentes en la década de los setenta, cuya urgencia provocaba que el relato testimonial diera cuenta, principalmente, de la realidad inmediata sin profundizar en su reflexión.

LITERATURA TESTIMONIAL EN URUGUAY: EXPERIENCIAS CARCELARIAS DE EX PRESAS POLÍTICAS

Una definición bastante detallada respecto a lo testimonial es la que entrega Jaume Peris (2014), quien afirma identificar tres líneas características:

En primer lugar, la representación de un acontecimiento o proceso violento (político o no) realmente ocurrido, del cual el texto desea dar cuenta y, en la mayoría de los casos, denunciar, hacer visible o construir su memoria. En segundo lugar, la presencia de una voz subjetiva que garantiza la veracidad de lo ocurrido, y que vincula la narración del acontecimiento con su circunstancia y su punto de vista. En tercer lugar, la construcción de una versión diferente, cuando no opuesta, a las narrativas institucionales y oficiales sobre el pasado reciente. En ese sentido, muchos de los analistas culturales han vinculado la emergencia de la literatura testimonial a la búsqueda de canales nuevos de expresión para las comunidades subalternas (10-11).

Estas cualidades que le dan forma al testimonio permiten, también, reflexionar sobre las transformaciones que se han venido dando entre las obras testimoniales latinoamericanas de los

\footnotetext{
${ }^{3}$ En la solapa del texto de la segunda edición.
} 
años setenta, muy ligadas a los discursos de resistencia, heroísmo y lucha contra las dictaduras militares, y las elaboradas en la década de los noventa, vinculadas con el rescate de la memoria y la defensa de los derechos humanos (Peris, 2014).

La indiscutible transformación del discurso testimonial da paso a su redefinición, tanto en la academia como en el Premio Literario Casa de las Américas, principal organismo cultural que en 1970 canoniza el testimonio al incorporarlo como categoría literaria en su reconocido premio. En el año 2000 lo que se venía conociendo como categoría de "Testimonio" será conocida como "Literatura testimonial". Inés Casaña y Jorge Fornet (2004) argumentan que: "[e]l segundo cambio significativo [en el Premio Literario] fue la decisión de refundar, bajo el nombre de literatura testimonial, lo que hasta entonces se conoció como testimonio, espacio que en la práctica estaba siendo ocupado -aparte de por el testimonio propiamente dicho- por géneros más o menos afines como memorias, biografías, reportajes, etc." (5-6).

Esta redefinición de lo testimonial trae consigo algunas disyuntivas que pueden surgir a la hora de analizar y valorar su discurso, ya que como señala Peris (2014) la definición de "literatura testimonial" es un arma de doble filo que busca, por un lado, entregarle a las obras "dignidad literaria y visibilidad académica y editorial", pero por otro, esa valoración artística las separa de la confrontación política y social que en sus inicios les dio sentido, y al tratar de integrarlas en el espacio literario disuelve su carácter no ficcional. Para Fabbri el concepto de "literatura testimonial" no es lo mismo que un testimonio "es una obra literaria en la cual, partiendo de la experiencia o las experiencias de una o muchas personas en un lugar y tiempo determinados, se logra construir un mundo, una propuesta, una verdad que el autor tiene para decir" (Hormilla, 2013). La verdad contenida en la obra testimonial, que se configura en el difuso entramado de lo literario, será lo que posibilitará reivindicar los espacios de memoria, abiertos a través de la escritura, desde un lenguaje subjetivo que ayudará a hablar del trauma provocado por el encierro, la violencia y la represión.

\section{PRÁCTICAS TESTIMONIALES CONTRA EL SILENCIO Y EL OLVIDO}

En América Latina el paso de los regímenes dictatoriales a los gobiernos democráticos estuvo marcado por la creación de leyes de amnistía destinadas a dejar impunes los delitos cometidos por agentes estatales y militares en periodo de dictadura, condenando a la sociedad violentada al más profundo camino del silencio y el olvido. Un claro ejemplo de ello es el caso uruguayo y su conocida Ley de Caducidad de la Pretensión Punitiva del Estado creada en 1986, definida por Ana Buriano (2012) como "el núcleo duro de la impunidad" (103), ley que deja clara la idea de dar vuelta la página de los episodios traumáticos acontecidos en periodo de dictadura:

\footnotetext{
A la salida de la dictadura uruguaya, el régimen transicional post-autoritario y la sociedad enfrentaron los legados del terrorismo de Estado implementando una de las políticas de negación y silenciamiento de las violaciones de los derechos humanos durante una de las dictaduras cívico-militar más extremas de la región. Estas políticas en Uruguay fueron llamadas "políticas de Olvido" (1985-2001) en círculos no-gubernamentales y académicos y fueron popularmente más conocidas como "políticas de impunidad” (Fried, 2016: 2-3).
} 
Lo interesante es que esta empresa de silenciamiento de la memoria provoca, específicamente en Uruguay pero también en países como Argentina y Chile, el interés por el rescate del pasado reciente, potenciándose aún más en el año 2000 para "romper el silencio sobre las responsabilidades y participación del Estado y abrir el debate cívico nacional ante los abusos de los derechos humanos" (Fried, 2016: 5). En Uruguay, además del impulso que promueven los procesos judiciales acontecidos en todo el Cono Sur, las Marchas del Silencio desarrolladas desde 1996 y convocadas por Madres y Familiares de Uruguayos Detenidos Desaparecidos y otras organizaciones, permiten ir orientando y definiendo la importancia del trabajo por la memoria y la defensa de los derechos humanos.

Los testimonios, como otra práctica de recuperación de la memoria colectiva, le entregan al superviviente de la violencia de Estado un rol fundamental en la reconstrucción de la historia y su discurso, de alguna forma, se cubre de credibilidad, aceptación y denuncia. Los testimonios uruguayos que nacerán a fines de los años noventa, tendrán como principal temática el encarcelamiento, pues se destaca como la medida represiva que caracteriza al régimen dictatorial del país:

[E]l aislamiento carcelario será el tema crucial en los testimonios, puesto que a diferencia de otras dictaduras del Cono Sur en las que se practicaron fusilamientos sistemáticos Chile - o desapariciones forzadas masivas -Argentina-, la modalidad represiva que caracterizó al régimen uruguayo fue el encarcelamiento masivo y prolongado (Lorente, 2016: 288).

Estos escritos testimoniales ya no enfatizarán el "deber del combatiente", tan presente en los testimonios de los años previos y sucesivos al golpe de Estado, pero tampoco se centrarán en la "obligación de ser víctimas" (Lorente, 2016). Lo que se quiere es desarrollar un frente de lucha a través de la práctica testimonial, tanto judicial como literaria, la que debe ser capaz de trasmitir, desde la experiencia subjetiva, una narración que dé cuenta de los episodios carcelarios a los que fueron enfrentados los militantes, y que se contraponga a las políticas del silencio instauradas por el Estado: "[e]n una contraposición entre silencio y voz, aislamiento y subjetividad colectiva, la narrativa testimonial sirve para reconstruir al sujeto testimonial a partir de su dimensión política, desde su historia de la militancia a la historia de la resistencia en los penales y cuarteles" (Forcinito, 2015: 536). El deber de memoria definido por Paul Ricoeur como el "deber de no olvidar" (2010: 51) cobrará gran importancia por la necesidad de contar y dejar evidencia de la experiencia de violencia y de encierro sufridos en el aislamiento carcelario. La figura del sobreviviente será cargada de una obligación moral, de una poderosa deuda que lo obliga a testimoniar para evitar que siga funcionando el proceso de impunidad latente en el país (Fried, 2016).

\section{VOCES FEMENINAS DESDE LA EXPERIENCIA CARCELARIA}

Las escrituras realizadas por mujeres en los talleres convocados por ex presas políticas del Penal de Punta de Rieles, así como la serie de testimonios que emergen en Uruguay a fines de la década de los noventa 4 , significarán un "aporte a la historia del testimonio político en el

\footnotetext{
${ }^{4}$ Ver en Alfredo Alzugarat (2007: 199)
} 
Uruguay" (Alzugarat, 2007: 202), puesto que contribuirán al conocimiento de la experiencia carcelaria desde un enfoque femenino. El resurgimiento del tema carcelario (ya antes trabajado en la década de los sesenta, pero desplazado a fines de los años ochenta), marcará el desarrollo de una segunda etapa testimonial en Uruguay (Alzugarat, 2007) que destacará por la construcción de la memoria a través de la participación femenina la que aportará al relato la reconstrucción de una memoria plural, la posibilidad de que los testimonios sean "ficcionados" y romper con el cerco de la cárcel y lo político por testimoniar desde cualquier lugar, no solo desde la voz militante (Blixen, 2010).

Este distanciamiento del testimonio originario dará paso a decir lo que se vivió, ya no desde la inmediatez y veracidad de una VOz (predominantemente masculina), partícipe de los sucesos histórico-políticos, sino desde una voz femenina reflexiva que entreteje lazos solidarios y organiza redes de protección y resistencia frente a la opresión (Alzugarat, 2007).

\section{EL TIEMPO Y LA MEMORIA: LA RECONSTRUCCIÓN DEL "YO”}

Oblivion inicia con la salida de la protagonista del Penal Punta de Rieles en 1985, es el modo que tiene Fabbri de comenzar a dar testimonio de su experiencia carcelaria: " $[\mathrm{t}]$ engo que empezar del final. Tengo que inventar algún final, aunque sea provisorio, para poder empezar. Mi final empieza en Jefatura, en una celda del cuarto piso, a principios de marzo. Era el año 85" (2012: 21). Así, su relato in extrema res, además de contextualizar el momento de su liberación, le permite abrir su discurso hacia el tiempo del pasado.

El viaje que emprende busca ir a los recuerdos que quedaron guardados en la memoria. Dichos recuerdos, que se articulan desde la voz subjetiva de un "yo", estarán en constante interpretación y reinterpretación, pues es ese desplazamiento al pasado el que permite entender el presente. Anna Forné (2010) identifica en Oblivion una memoria reinterpretativa 5 , cuya dinámica pondrá a trabajar al lenguaje en nuevas formas de decir el trauma, reelaborando los elementos que llegan del pasado al presente.

En esta búsqueda de los recuerdos, Fabbri vive una constante tensión entre el "yo" del pasado y del presente, principalmente por el vínculo de su memoria con un pasado doloroso: "todo es verdad aunque no lo parezca, aunque parezca ahora que le pasó a otras personas, entre ellas a una que se parecía a mí y que guardaba algo para su futuro, el presente mío de hoy" (Fabbri, 2012: 49). Ese distanciamiento que se manifiesta en el "sentirse otra" se observa en ciertos apartados en los que, además de mencionar explícitamente sentirse ajena, Fabbri emplea la tercera persona para dar a conocer acontecimientos de su pasado, principalmente vinculados a su rol como militante: "[a]nduvo armada, pero nunca había tenido que usar un arma" (2012: 76). El espacio que ocupa esa "otra" del pasado no sólo tendrá que ver con las acciones desarrolladas o con su identidad militante, sino con su esencia misma, la "otra" ocupa cada aspecto de su ser, especialmente su cuerpo:

\footnotetext{
5 Concepto que acuña Nelly Richard (2001) quien la define "como un proceso dinámico que constantemente reelabora los sentidos del pasado al introducir las facetas recónditas de vivencia traumática en el seno de la lengua objetivada, generando nuevos lenguajes y superficies de inscripción que permiten configurar las memorias de la dictadura más allá del lenguaje referencial del testimonio judicial” (cita en Forné, 2010: 65).
} 
Inventaron un personaje con su nombre y ese personaje estaba en su cuerpo. ( $\mathrm{Y}$ así lo trataron, después, como si fuera el de la otra.) [...]

Y a ella, a la otra, la tuvo que llevar por mucho tiempo hasta que por último, muchos años después, cuando ya había salido lo entendió. Ella no podía echarla de su cuerpo. No solo los milicos la trataban (a ella, la verdadera) como si fuera la otra (la peligrosa). También la gente, la que la quiso y la abrazó y la cuidó cuando salió. Así la miraban y ella sintió que había una equivocación que no podía a cada paso aclarar (2012: 93-94).

Se observa en el fragmento anterior, que alude al juicio que condena a Fabbri a prisión, cómo su cuerpo comienza a contener dos identidades contrapuestas: una peligrosa e inventada; y otra que se considera verdadera. La sensación del cuerpo habitado por otra identidad no es comprendida en el momento de los hechos, sino después, en la distancia de los acontecimientos que determinaron su destino de encierro. Peris (2008) acude a la aporía de la impropiedad del propio cuerpo $0^{6}$ para referirse al modo en que opera la dinámica concentracionaria en la represión del individuo la que "tendría como objetivo y efecto la destrucción de la subjetividad y la identidad” (67), el núcleo de dicha destrucción estará centrado en el propio cuerpo del prisionero.

De este modo, la nueva identidad que aparece en el juicio y que amenaza con borrar el "yo verdadero" llevará a Fabbri a luchar constantemente para evitar que se superponga a la identidad que considera verdadera: "[h]abía tenido la sensatez de no confundirse con el personaje. Eso le regalaba una satisfacción. La otra no había logrado sacarla de su lugar. Lo que no había podido evitar era vivir su destino" (2012: 94). El cuerpo ocupado por la "otra" (violenta, peligrosa, armada) sufrirá el destino desgarrador del encierro y la tortura, y para hablar de ello el uso de la tercera persona singular será necesario. El “yo" ajeno también es evidente en la escritura:

[L]as cartas ya no están. Mi madre las guardaba y una vez me habló de ellas, después que salí. En ese momento no quise verlas. Sentí algo como vergüenza, como si alguien muy distinta las hubiera escrito y yo supiera que no iba a creer en ellas (Fabbri, 2012: 28-29).

La voz narrativa teme reencontrarse en las cartas, por ello, la distancia entre presente y pasado aparece persistentemente: las cartas son el vestigio de un periodo traumático que configura a la Fabbri privada de libertad y etiquetada como violenta. Francesc Roca define el trauma "como una vivencia que el sujeto percibe como extraña a sí mismo, como ajena a su biografía, como un accidente" (1998: 77), lo que se evidencia en la distancia que establece Fabbri entre el sujeto que escribió las cartas en el pasado y el que no quiere verlas en su presente. La escritura (del mismo modo como lo hace el cuerpo al recordar el "yo" del pasado):

Se realiza en Oblivion desde la otredad con el mismo yo, desde la extrañeza con la propia persona que invade a la narradora a la hora de mirar el pasado. Es esta ruptura reflexiva con el tiempo de la experiencia y la protagonista de éste que engendra un tiempo de escritura protagonizado por el proceso de intelección e intelectualización de las huellas del pasado (Forné, 2010: 68).

Además de establecer una relación de otredad con el "yo" del pasado, reacción usual frente a un evento traumático, el personaje en Oblivion cuestiona constantemente el modo en que los

\footnotetext{
${ }^{6}$ La idea de impropiedad del propio cuerpo es referida por Albert Sucasas (2000).
} 
recuerdos llegan a su memoria. Strejilevich (2006), a propósito de lo que afirma Hannah Arendt, menciona que a las mismas víctimas les resulta difícil creer en sus propios recuerdos. Dicha problemática se verá reflejada a lo largo de todo el testimonio de Fabbri, sobre todo cuando menciona: "sé que tengo que desconfiar de mis recuerdos" (2012: 61) porque hay recuerdos tramposos y evasivos.

El tiempo del pasado que se busca traer al presente es dinámico y complejo, por lo que se configura a través de una variedad temporal que afecta al tiempo de la escritura, pues solo de ese modo es posible recordar no los hechos —a los que Fabbri insiste no prestarles atención-, sino a todo aquello que permanece en el silencio y que se vincula con las experiencias de violencia y dolor vividas en el íntimo espacio carcelario compartido con sus compañeras de militancia. Así, los recuerdos se levantan como un entramado de visiones y sensaciones que se entremezclan y se cruzan para darle vida a la memoria. A propósito de ello menciona Strejilevich:

Para que un recuerdo de ese tipo pueda manifestar su verdad tiene que darle lugar a memorias que irrumpen en desorden, con discontinuidades, blancos y silencios. Las imágenes pueden ser de olores y de sonidos, las escenas pueden aparecer y desaparecer como en un sueño, las conexiones con la vida cotidiana pueden faltar (2006: 14).

De este modo, Fabbri intentará organizar sus recuerdos en núcleos temporales ${ }^{7}$ vivenciales que permitan ir hilando la experiencia, a pesar lo complejo de la tarea. Se logran identificar tres núcleos temporales que cristalizan su experiencia carcelaria. Por un lado, se encuentra el tiempo del principio que comparte cualidades con el tiempo del final. Ambos están marcados por sonidos fuertes, por el lento transcurrir del tiempo, por el temor y la espera, así se menciona: “[e]l tiempo del final estuvo lleno de sonidos fuertes, en eso se parece al del principio. También en su lentitud" (2012: 25), o "[e]l tiempo del final estuvo lleno de temor como el primero, además de ser lento como él” (2012: 27). El tiempo del principio está determinado por el momento del encarcelamiento y la incertidumbre del qué vendrá, por ello predomina el miedo y la lentitud de los días; el tiempo del final está ligado a la pronta liberación, a la despedida de un espacio en el que convivió largos años con las compañeras de militancia, es un tiempo que conlleva cambios:

Pero yo lo recuerdo muy bien y lo quiero. Era un tiempo de despedidas, nos despedíamos como si nunca más [...] Ahora pienso que nos estábamos despidiendo no solo de nosotras sino también de una vida que, fuera como fuera, había sido la nuestra, la única, la que habíamos hecho juntas. Le teníamos miedo a lo que venía, por supuesto, pero era también muy difícil dejar aquel mundo atrás (2012: 25).

La vida fuera del penal es incierta y se vuelve difícil decirle adiós: "de alguna forma, y eso me sorprendió, quería quedarme en ese dolor, en ese tiempo" (2012: 25). La huella traumática que deja el periodo de prisión reflejada en el no querer distanciarse del espacio carcelario, se

\footnotetext{
${ }^{7}$ A propósito de la importancia del tiempo en el sujeto, Judith Nieto afirma: " $[\mathrm{L}]$ a vida debe asumirse, sea individual o colectiva, como unida al tiempo, dado que procura la reflexión sobre la realidad y el contenido social que la hace posible; pues bien se sabe que la vida no acontece en un vacío, se da dentro del tiempo y su interés, en una reflexión sobre la memoria histórica, permanece abierto a una relación dialéctica de pasado y futuro, desde la cual ayuda a explicar el presente y a comprender los diversos y complejos cambios experimentados día a día por las sociedades" (2006: 86).
} 
evidencia mucho más en la tercera instancia temporal destacada por Fabbri y denominada tiempo del medio: "los años del medio se cierran a mis recuerdos como un muro de piedra" (2012: 54). Es un tiempo caracterizado por ser largo, impenetrable, al que es posible aproximarse solo a través de la protección y del amor de las compañeras de prisión que la entendieron y la protegieron: “[a] los años del medio puedo empezar a mirarlos por la hendidura de ese amor. Y puedo ver ahí otros frentes, otras penas que no venían de ellos" (2012: 54). Dichas penas no sólo se vinculan con la violencia y la tortura provocadas por el aparataje represor, sino con la dureza con la que actuó la organización guerrillera exigiendo compromiso y resistencia.

Es así como el tiempo del medio no se quiere recordar, él está vinculado a los sucesos dolorosos y traumáticos que determinaron las relaciones de compañerismo y compromiso en la lucha dentro de la prisión. Es un tiempo que puede entenderse como un "hiato en la temporalidad subjetiva, dado que se trata de un suceso que amenaza precisamente con producir una disolución del Yo y por tanto no puede inscribirse en la lógica del deseo del sujeto" (Peris, 2008: 56). Es un tiempo que violenta al sujeto y lo aproxima a los eventos que marcaron su memoria y que desea mantener ocultos, distantes y ajenos. Sin embargo, Fabbri es consciente de que sólo interrogando a ese dolor, a esos años, podrá dar paso a la reconstrucción de su memoria.

El trabajo de memoria, por tanto, no estará asido a los hechos "porque el relato de los hechos podía esconder todo lo que uno quisiera esconder. El relato de los hechos está unido al recuerdo y sé que hay que desconfiar de los recuerdos" (2012: 54-55); sino al dolor alojado en el cuerpo que resistió tanto: "[y] me digo: ¿quién puede interpelar a su memoria?, ¿quién va a preguntarle a su piel y a sus huesos lo que saben? Nosotras nos debemos la vida. También el dolor. Ese otro dolor que vino de nosotras, el que no queremos recordar” (2012: 55).

El deseo de hacer visible ese dolor desde el presente del que recuerda, sólo será posible buscando en los años del pasado los que reclamarán ahondar en el cuerpo que contuvo a la otra intrusa y que resistió la tortura del aparataje represivo y las exigencias de la organización militante. Pero el cuerpo sufriente se resistirá, en algunas ocasiones, a esa búsqueda de la memoria y será él quien decida qué será contado y qué será guardado: “[p]ero yo intentaba mirar los largos años del medio por una ranura cualquiera. Empecé a verlos y otra vez la mirada se fue hacia un paisaje mejor. Un paisaje que ella elige. La mirada se cambia de lugar y busca otro tiempo" (2012: 60). De ahí la fuerte idea que hilvana el trabajo de memoria que intenta desarrollar Fabbri cuando menciona que "la memoria no es lo que pasó, son sus huellas" (2012: 55), vestigios que están alojados en su cuerpo que tratará de evocar y, luego, plasmar en la escritura.

\section{LA ESCRITURA Y EL DOLOR ESTÁN EN EL CUERPO: LA POSIBILIDAD DE DECIR}

Según Ricoeur (2010), “[a]cordarse es no sólo acoger, recibir una imagen del pasado; es también buscarla, 'hacer' algo" (81). Dicha definición le dará forma al acto de rememoración entendido por Bergson como esfuerzo de memoria (desde un enfoque cognitivo) o por Freud como trabajo de rememoración (desde un enfoque pragmático). Ricoeur enfatiza que ambos enfoques se superponen para darle sentido a la rememoración, así: "el reconocimiento que corona la búsqueda conseguida designa la cara cognitiva de la rememoración, mientras que el esfuerzo y el 
trabajo se inscriben en el campo práctico" (2010: 81-82). Sin embargo, la búsqueda y el esfuerzo por conseguir "acordarse de algo" no siempre es asegurada, como afirma Ricoeur: "[n]o todo el que busca encuentra necesariamente. El esfuerzo de rememoración puede tener éxito o fracasar. La rememoración lograda es una de las figuras de lo que llamamos la memoria 'feliz"' (2010: 48).

En Oblivion existe un intento de rememoración que se configura a través de imágenes que, aun siendo confusas, le dan forma a la historia vivida. La memoria marcada por esta confusión, producto del pasado de violencia y represión, buscará incansablemente hilvanar la experiencia. Elizabeth Jelin menciona que "[e]n lo individual, la marca de lo traumático interviene de manera central en lo que el sujeto puede y no puede recordar, silenciar, olvidar o elaborar" (2002: 11). Así, el trauma, evidente en los momentos en que el relato es imposible y se cierra al intento de rememoración, provocará en la voz narrativa una desarticulación de los recuerdos que llegan a la memoria imposibilitando su continuidad. El testimonio buscará posibilitar la articulación del entramado de ideas confusas en una narrativa posible aunque siempre amenazada por el trauma. La "débil narratividad" presente en los testimonios de supervivientes, como aclara Peris (2008) "no debe leerse como un fracaso estético, sino como una señal del modo en que los supervivientes trataron de articular en el discurso la experiencia vivida en los campos" (57). De este modo, se observará que la voz narrativa en Oblivion tratará de articular su experiencia carcelaria desde la fragmentación del relato vinculado a las imágenes de un pasado doloroso.

Así, el universo que se dibuja en Oblivion "pasa por la materialidad de la naturaleza muerta de las imágenes de la cárcel hasta llegar a las facetas más recónditas solamente perceptibles desde la distancia" (Forné, 2010: 72). Los recuerdos que se establecen en imágenes no cobran sentido sin realizar el necesario acto de búsqueda ${ }^{8}$ el que permitirá ir al pasado y traerlo al presente. De este modo, el recuerdo materializado en la reja, el patio, el corredor, el trabajo, cobra sentido solo cuando la voz narrativa decide ir en su búsqueda: "[m]iraba el pasado desde afuera (es raro decir esto). Y me metí en él como en el mar, a oír ese silencio” (Fabbri, 2012: 12).

Para poder introducirse en aquel pasado tortuoso, Fabbri debe interrogar a su propio cuerpo, puesto que él contiene el recuerdo y el dolor de aquellos años. Desde la perspectiva psicoanalítica Silvia Bleichmar plantea que "el cuerpo es la propiedad última del ser humano" y que "es a partir del cuerpo que el sujeto se reconoce a sí mismo" 9 . Esta idea podría explicar el necesario vínculo entre cuerpo y recuerdo que enfatiza Fabbri: el cuerpo representa su propio "yo" materializado que busca enunciar su verdad. Carlos Liscano en el prólogo a la primera edición de Oblivion reflexiona:

El recuerdo está en el cuerpo. Él es quien elige las palabras que dirán lo que se recuerda. Lo que no se recuerda no será nunca olvidado. Porque si no fue palabras, algo dicho o pensado o escrito, no puede olvidarse. Entonces, un día, el recuerdo no olvidado, no

\footnotetext{
${ }^{8}$ Sobre el proceso de búsqueda de los recuerdos Bergson citado por Ricoeur (2010) señala: "un recuerdo, a medida que se actualiza, tiende a vivir en una imagen; pero la proposición recíproca no es verdadera, y la imagen pura y simple sólo me transportará al pasado si efectivamente fui a buscarla al pasado, siguiendo así el proceso continuo que la llevó de la oscuridad a la luz" (77).

9 Entrevista realizada por María Esther Gilio publicada en el Semanario "Brecha" (Montevideo, 31 de mayo de 2002).
} 
hecho palabras, salta del cuerpo y se vuelve presente y vuelve a doler como en su día. Se recuerda para que deje de doler (2012: 7)

El cuerpo será el espacio en el que estará contenida la experiencia, él hablará o callará según la intensidad del dolor; él permitirá o no escribir y entender el pasado. El cuerpo de la vOz narrativa habla pero no a través de las palabras, para ella las palabras vienen después porque primero están las sensaciones corporales:

[E]l cuerpo recibe y calla. O habla por sus vasos y otros conductos antes que por la palabra que sale de la boca. (Ella viene siempre después, a veces se adelanta, casi nunca sabe.) el cuerpo recibe y habla por sus capilares, vasos más finos que un pelo, con la sangre despaciosa adentro de ellos (2012: 86).

Serán las percepciones sensoriales del cuerpo ${ }^{10}$ las que permitirán en Fabbri articular su "yo" con la experiencia traumática.

Forcinito (2015) analiza la idea del cuerpo en diversos testimonios uruguayos escritos por hombres desde la propuesta de Alain Badiou quien reconoce en el sujeto un cuerpo sufriente y un cuerpo pensamiento. El cuerpo sufriente es el cuerpo que vive el dolor que provoca la tortura y el encierro los que se manifiestan en un grito desarticulado, es el cuerpo de la víctima; el cuerpo pensamiento, entendido desde la idea de cuerpo-testigo, hace visible desde una voz articulada la denuncia de las violaciones a los derechos humanos y se instala desde una subjetividad éticopolítica. El cuerpo sufriente es incapaz de articular su voz pues se encuentra sometido a la violencia del perpetrador, quien hace visible su vulnerabilidad; pero el cuerpo pensante se articula como la voz posible. Es en el paso del cuerpo sufriente (víctima) al cuerpo pensante (testigo) donde los supervivientes tratarán de trasmitir la experiencia traumática a través de la escritura.

Respecto a lo anterior, es posible identificar en Oblivion escenas que refieren al cuerpo sufriente atormentado por la tortura:

Uno no conoce tanto a su cuerpo. Lo que él resiste. Lo que uno resiste lo sabe solo después. No antes de que empiecen. La parte de antes es la peor, por todo lo que uno no sabe. Ignora lo que ellos van a hacer y desconoce también lo que uno mismo va a hacer. Uno tiene miedo de sí, de fracasar. Queríamos ser enteros, no entregar nada ni a nadie.

El tacho era un tanque grande con agua maloliente y ahí te metían. Se ve que tenían mucha fuerza. A mí me agarraban de las piernas y yo colgaba con la cabeza hacia abajo [...] ellos me agarraban así para ahogarme y manosearme con manos grandes de hombre antes de meterme en el agua donde vi, por último, la cara de mi padre (2012: 87).

La tortura se manifiesta aquí como un espacio incierto en el que el cuerpo no sabe cómo reaccionará ni a qué se enfrentará. Es un espacio difuso que mantiene a la víctima en la más entera agonía, incluso momentos antes del procedimiento. Por eso Fabbri afirma que "[e]l lugar del dolor es el cuerpo. El del miedo también (dónde habita el miedo sino allí, dónde chorrea el sudor de tanto miedo, dónde el pavor al otro si no es allí, en un cuerpo)" (2012: 88). En esa

\footnotetext{
${ }^{10}$ Peris afirma que "[e]l cuerpo y sus percepciones sensoriales se ofrecen como el elemento que puede taponar esa distancia insalvable entre sujeto y experiencia, situándose entre ambos y articulándolos recíprocamente” (2005: 265)
} 
dislocación corporal se reconoce la situación tortuosa del "yo" amenazado, manoseado, violentado; es una voz que se sabe indefensa, que ha perdido todo tipo de protección: "[p]ero al ritmo que sea nos sacamos una capa y la otra hasta quedar sin nada, sin la piel con la sola carne desollada. Un cuerpo inerme que se sabe así" (Fabbri, 2012: 87). La piel, donde se encuentra el margen entre el "yo" y los otros en el espacio, arrancada de su función protectora, deja al cuerpo en carne viva, de tal modo que el "yo" en la tortura está expuesto a la más completa vulneración.

Pero el cuerpo sufriente de Fabbri en el periodo de prisión, no sólo se manifiesta frente al dolor de la tortura, es un cuerpo que también debe cumplir una función: él resiste, registra y guarda, para luego, de algún modo, escribir la experiencia. Será la mirada y la labor de los ojos como parte esencial del espacio corpóreo e identitario, los principales vehículos de resistencia y registro, por ser lo único que dentro de la prisión le pertenece:

(Solo las miradas eran nuestras. Las palabras dichas, igual que las escritas pasaban por ellos. Hablábamos por unos teléfonos, ellos escuchaban. Las manos no se podían levantar, hacer algún gesto. Otra vez los ojos, siempre los ojos que no se cansan, que no podían descansar. Y a veces ellos preguntaban, los ojos de los familiares, y los nuestros a veces querían o tenían que callar) (2012: 36).

La comunicación minimalista a la que alude Feitlowitz (en Strejilevich, 2010), notoria en las relaciones carcelarias desarrolladas en Oblivion, enfatiza en una nueva forma de comunicación vinculada a una manera mínima de hacer contacto con otros y empleando gestos, miradas, señales que pasaren desapercibidas por los represores a simple vista. De esta manera, la mirada en Oblivion, como prolongación de la propia identidad, atraviesa los espacios prohibidos por el aparataje represivo y es capaz de decidir comunicar o no; la mirada rompe las barreras de aislamiento impuestas por el sistema carcelario porque se prolonga más allá de la materialidad del cuerpo y de las cosas lo que permite establecer contacto, ya sea entre compañeras o con sus mismos familiares. El ojo como "el soporte de la mirada" (Sartre, 1993: 334) tendrá la trabajosa labor de mantenerse atento y abierto para permitir la captura del espacio y de los sujetos.

Sartre en su texto El ser y la nada (1993) realiza un profundo análisis sobre la mirada donde enfatiza cómo ésta hace visible a los sujetos y las cosas convirtiéndolos en objetos de quien los mira, ubicando al sujeto que "mira" en una posición de dominación frente al que es "mirado". Esta especie de dinámica de poder a la que alude Sartre es posible evidenciarla en el testimonio de Fabbri teniendo la mirada como factor determinante en la lucha interna que se propusieron las prisioneras durante su periodo de encarcelamiento, principalmente porque la mirada constituyó no sólo un frente de resistencia, sino también de lucha por los espacios y la privacidad:

Las rejas permitían ver. Veíamos nuestro interior, no para afuera, que para eso estaban nuestras ventanas pintadas. También ellos nos podían ver. Todo este asunto de las visibilidades era cambiante [...] Nosotras también las mirábamos [...] Con la cara bien fija por los barrotes, mover los ojos. Solo los ojos, lo más que dan para el costado [...] A veces ellas entraban y se quedaban mucho rato en el corredor, y algunas veces, por periodos, se quedaban en forma permanente. Entonces la vida de la celda cambiaba, porque ellas estaban mirando todo (2012: 34-35). 
Ver a escondidas y en silencio a las represoras constituye poseer una verdad que la reja de la prisión debería impedir, puesto que su función es controlar los cuerpos y sus libertades; pero también, tener esa visión prohibida permite liberar el espacio interno de la celda sólo visto, en esos momentos, por las mismas prisioneras. Sin embargo, cuando éstas son vistas por las celadoras, el espacio íntimo de libertad y la posibilidad de mirar sin ser vistas, se pierde y cae bajo el dominio de la mirada atenta de las "otras", lo que provoca que la dinámica interna de la celda se modifique. Este frente de lucha que es la mirada, con todos los inconvenientes del poder o no poder ver, significará el principal elemento reaccionario que poseerán las prisioneras frente al silenciamiento y la vigilancia: "[y] cuando digo pudimos me refiero a que pudimos mantener la mirada en donde queríamos dejarla. Otra vez la mirada. Acaso estuvo ahí la pelea, acaso era eso lo que defendimos: una forma nuestra de mirar, un paisaje en donde quedarnos, no los senderos del sinsentido" (Fabbri, 2012: 41). La mirada se erige como un sitio de resistencia, lucha y cohesión al que las fuerzas coercitivas no pudieron ingresar ni aún menos eliminar.

La mirada, además, es la que elige, incluso en el momento de la rememoración, qué será lo recordado y lo dicho: "[a]hora que ya pasó mucho tiempo de todo aquello la mirada otra vez vaga y elige, selecciona. Nos protege, ella decide siempre lo que podemos contar para que no nos agarre la planta y nos asfixie" (2012: 44). Será ella anclada en el cuerpo la que retornará al pasado y seleccionará lo que el cuerpo puede decir. La reflexión que llevará a Fabbri a escribir su experiencia exige transformar su cuerpo de sólo dolor, de puro sufrimiento, a idea, pensamiento.

De este modo, la labor de resistir y registrar que el cuerpo había asumido en el pasado, concluirá en el decir, por eso es que Fabbri no sólo une su cuerpo al dolor y al miedo, sino también lo hace a la escritura:

El lugar de la escritura es el cuerpo. Si la palabra escrita no pasó por el cuerpo, por su íntima oscuridad, es una palabra débil, difícil de creer. El cuerpo recibe y devuelve otra luz o un silencio, escribe. Él teje los pensamientos adentro de nosotros. Agarra las puntas de las ideas y las ata, y así las palabras quedan unidas por algo muy leve que las viste de un sentido nuevo y desconocido que no nos pertenece (2012: 84).

Como la escritura se encuentra vinculada al cuerpo y éste ha sido constantemente agredido, desarticulado y aislado, será una escritura que tenderá a la fragmentación y a la dificultad de trasmitir la experiencia a través de las palabras. Peris (2008) señala que frente a la labor de testimoniar el superviviente que ha vivido el dolor extremo "debía rearmar su propia relación con el lenguaje [...]; esto es, construir una posición de enunciación desde la cual ese derrumbamiento de la subjetividad y sus referencias externas pudieran ser representadas" (52). El "derrumbe subjetivo" que tenderá a manifestarse en Fabbri será el causante de la difícil relación entre las palabras y los recuerdos: “¿[c]ómo escribir? ¿De qué otra cosa? Si aquel pasado era lo único real, lo único de lo que importaba escribir. Esa había sido su vida. Allí creció, aprendió y olvidó. Allí amó, allí se hizo, en fin, quien era. Y ¿qué palabras podrían soportar la verdad necesaria para que alguien, otro, creyera en ellas?” (2012: 76). Sin embargo, Fabbri atiende a su deseo de escribir la experiencia y se vuelca a la escritura utilizando las palabras que, de algún modo, lo posibiliten.

De allí la importancia del concepto de huella que emplea Fabbri cuando menciona "la memoria no es lo que pasó, son sus buellas" (2012: 55, 80). Las huellas son el resultado de su 
trabajo de memoria, son el vestigio de lo que queda de la experiencia vivida en el pasado. Por eso es que Fabbri defiende la idea de que su misión de escritura no estuvo sujeta a una labor de historiar ${ }^{11}$, sino a dar cuenta de los rastros del pasado que quedan en su memoria. Esta dicotomía entre historia y memoria a la que se enfrenta la voz narrativa se vincula con la responsabilidad que se le impone al superviviente de " $[\mathrm{u}] \mathrm{n}$ deber de escribir o testimoniar de algún modo acerca de un pasado que se escapa y que debemos trasmitir, como en una carrera de postas, a los que siguen" (Fabbri, 2012: 52). Este carácter de memoria obligada que postula Ricoeur ${ }^{12}$, se plantea como tarea ineludible en el ejercicio de construcción del pasado reciente: todo el que vivió la violencia de Estado se ve en el deber ético de testimoniar. Pero en el testimonio de Fabbri la el deber de memoria se plantea más bien como una idea de justicia ${ }^{13}$ consigo misma y sus compañeras, así Fabbri en el proceso de recordar y contar, dice Liscano, "[c]onstruye una protección para sus muertas queridas, las que no consiguieron ver la libertad. Las que ya no pueden organizar el olvido propio. No es que se lo proponga, pero tal vez las ayude, que tengan un lugar en el recuerdo que Edda les organiza" (2012: 9).

Este rechazo a asumir el deber de escribir se traduce en la negación de una postura de verdad de los hechos, pues "no tuvimos más mérito que de haber elegido en algún momento quedarnos, acaso sin saber, seguramente sin saber lo que venía” (Fabbri, 2012: 52). Su deseo está en interrogar otros espacios de la memoria que en forma de huellas permitan hablar al silencio, a aquello que no se ha dicho: "[n]o quiero contar la historia, no tengo que historiar. Yo quiero escribir como ellos [los marineros] mi soledad, mi miedo y mi deseo” (Fabbri, 2012: 81).

La escritura como herramienta reconstructiva emergerá como instancia autorreflexiva: "[e]scribí para explicar y explicarme" (Fabbri, 2012: 12); una especie de catarsis invade el acto de decir, pues implica no solo dejar una huella, o trasparentar la experiencia, sino también reflexionar consigo misma a través de lo que el cuerpo contiene. Sin embargo, en Oblivion la escritura incorporará ciertos silencios, omisiones y olvidos que darán cuenta de la imposibilidad de testimoniar14 ${ }^{14}$ lo que se vivió tal y como sucedió. Strejilevich (2010) afirma que el superviviente vive una confrontación entre ver, decir y escribir la que se organiza a través de la labor artística donde se vinculan la ética y la estética. Será el lenguaje literario15 el que permitirá organizar las

\footnotetext{
11 Fabbri argumenta: "[e]l equívoco está en que yo no escribí sobre algunos hechos (ocurridos durante la dictadura y que protagonicé), o no principalmente sobre ellos, sino principalmente, y creo que en esto puse el énfasis, en lo que de ellos quedó en mí, en lo que damos en llamar memoria” (11).

12 “¿[C]ómo es posible decir 'tú te acordarás', por tanto, harás conocer en el futuro esta memoria que se da como guardián del pasado?” (Ricoeur, 2010: 119).

13 Aclara Ricoeur que "el deber de memoria es el deber de hacer justicia, mediante el recuerdo, a otro distinto de sí” (2010: 121). Al recordar hago justicia a otro, cuando no se olvida se hace justicia con otro. Ese “otro", presente o ausente, con el que comparto referentes o historias.

14 Afirma Peris acerca de la imposibilidad de testimoniar: "los testimonios, en realidad, de lo que dan cuenta es de la propia imposibilidad de testimoniar. Quizás sea esa la característica que los acerca tanto al lenguaje literario: más allá de su apariencia de referencialidad, el desgarro interno de los testimonios señala un desajuste esencial que la literatura no ha dejado de explorar desde los inicios de la modernidad: el abismo insalvable que media entre la realidad y su representación, entre el sujeto y el relato vital sobre el que se sostiene, entre la experiencia de la violencia y el lenguaje que trata de dar cuenta de ella" (2014: 17).

15 Nora Strejilevich apela al concepto de vozpoética: “[q]uizás la voz poética sea, por esta razón, la más apta para trasmitir las huellas de la tortura, que incluye la reclusión, el maltrato, y la liberación a un mundo que raramente se interesa por el tema” (2006: 14).
} 
ruinas de la historia vivida y plasmarla en la "página en blanco" que destaca Strejilevich, quien la define como un "espacio donde el evento se inscribe por primera vez y la memoria actúa creando un texto donde elabora su horizonte desde la subjetividad, o donde el narrador la reescribe para que ésta recupere su estatuto" (2006: 19).

El lenguaje, como lugar de refugio y de reflexión (Draper, 2014), articulará la experiencia mediante las palabras que, si bien son útiles, también son insuficientes, pues "[l]as palabras pocas veces hablan de verdad por nosotros, pocas veces pueden escuchar a la ciega memoria, copiar aquel murmullo" (Fabbri, 2012: 81). Sin embargo, son las palabras la única manera de trasmitir a otros las huellas de la historia vivida.

\section{¿ESCRIBIR LA HISTORIA? LA MEMORIA COMO DOLOR Y EL OLVIDO COMO PERDÓN}

Para escribir Fabbri tendrá que seleccionar las palabras que le dan sentido a su trabajo de memoria y debe hacerlo cuidadosamente para que no suenen vacías, sino que intencionen su discurso. La instancia de escritura dará paso al trabajo de duelo el que "se revela costosamente como un ejercicio liberador en la medida en que consiste en un trabajo de recuerdo" (Ricoeur, 1999: 36). De este modo, el trabajo de memoria que se nutre recíprocamente con el trabajo de duelo, buscará atender a los traumáticos recuerdos del pasado y traerlos al presente desde una postura que no implique anclarse al dolor del recuerdo, por ello es que entrelazar el trabajo de duelo al de memoria "[i]mplica poder olvidar y transformar los afectos y sentimientos, quebrando la fijación en el otro y en el dolor” (Jelin, 2002: 15).

Esta articulación entre memoria y duelo se concreta en Oblivion a través de un concepto que atraviesa toda la obra: el olvido, nombre con el que bautiza incluso su obra, y con el que se hace presente la paradoja de Fabbri mencionada al comienzo de este artículo. En Oblivion, la palabra olvido reemplazará a la de memoria ${ }^{16}$ porque esta última responde a las demandas del deber de escribir o testimoniar que exige el grupo de ex prisioneras atendiendo a una memoria casi absoluta, que no olvide nada ${ }^{17}$, un trabajo tan técnico como la labor del historiador. Sin embargo, el concepto de olvido se encuentra anclado a otra forma de memoria, que no significa borrar las huellas del pasado violento que vivió junto a sus compañeras, no busca una memoria vacía, sino que responde a mirar el pasado de manera crítica y reflexiva sin anclarse ni en el dolor ni en el resentimiento; el olvido, de algún modo, reflejará el trabajo de duelo. Una definición muy vinculada a lo anterior es la que entrega Ricoeur cuando menciona que "si puede evocarse legítimamente una forma de olvido, no será la del deber de ocultar el mal, sino de expresarlo de un modo sosegado, sin cólera" (2010: 591). De este modo, la idea paradójica de que el olvido puede estar unido a la memoria puede considerársela como una de las condiciones esta.

\footnotetext{
16 Lucas Salvi destaca como en Oblivion la voz narrativa se apropia del lenguaje (al remplazar el concepto de memoria por el de olvido) resignificándolo para articular una nueva propuesta de memoria alejada de la forma institucional: "Se hace así posible construir, en el lenguaje y sólo a través de él, un espacio situado más allá de la memoria, de la historia hecha institución. El nombre que el testigo da a este lugar, llamado ahora el olvido —oblivion- nos viene a demostrar una vez más de esta posibilidad infinita que se ofrece al discurso, en contra de las rejas agobiantes del lenguaje de la historia (2016: 258).

${ }^{17}$ Una memoria similar a la de "Funes el memorioso" (1986) de Jorge Luis Borges.
} 
Fabbri defiende la idea de que el individuo tiene un derecho al olvido: "[y]o no reivindico la necesidad del olvido. Lo que reivindico es el derecho del individuo a olvidar" (Hormilla, 2013); y es a ese derecho al que se ancla para poder contar su historia desde su propio trabajo de memoria cerrando las heridas que invitan a mirar el pasado desde el remordimiento, y que obligan volver a él sin dar paso a la reflexión. Pero, ¿qué es lo que Fabbri desea olvidar?, ¿qué dolor necesita sanar para poder escribir? El olvido no estará vinculado a la violencia ejercida por los represores, sino a la violencia interna de la guerrilla, a los dolores provocados entre las mismas compañeras de prisión; en definitiva, buscará hablar sobre aquello que se mantiene en los márgenes del silencio de su propia organización, desarticular el discurso que se ha establecido sobre qué se debe recordar, para dar paso a algo mucho más problematizador vinculado con aquello que se calla o se guarda, pero que marcó a la voz narrativa y el vínculo con sus compañeras. Por eso Fabbri sentenciará:

Memoria y dolor están pegados —escribí entonces-, perdón y olvido también. La palabra perdón no está de moda. Creo que parece antigua (seguro que lo es) o algo peor. Pero yo la puedo escribir y pronunciar. Tocarla como una piedra, mirarla, aprender de ella. ¿Qué tengo que perdonar? ¿Quién tiene que perdonarme? La piedra en el bolsillo. Pero no para ahogarme, para vivir. Sé que sin ella me ahogo. Tal vez con ella escriba (2012: 62).

Para que la paradoja de Fabbri —entre la memoria y el olvido - tenga posibilidad de concreción tendrá que buscar el perdón, cuya misión es la de "desatar, desligar al agente de su acto” (Ricoeur, 2010: 638). El perdón se vinculará tanto a las acciones de violencia realizadas por el propio "yo" cuando menciona "entendí que necesitaba olvidar mi dolor. Eso quiere decir, más precisamente, que necesitaba olvidar mi culpa, precisaba perdón y perdonarme" (2012: 12), como a las acciones cometidas por sus compañeras cuando afirma Liscano que "[n]o es para gritar ni para odiar que organiza los recuerdos. Quiere perdonar. ¿A quién? A todos, a ellas, a sus hermanas de la cárcel, las que la amaron y la sostuvieron. Las que le cuidaron la vida como si fuera propia" (2012: 9). El deseo de perdonar y perdonarse concluirá con el trabajo de memoria, ya que este buscará enfocarse en las acciones cometidas por la voz narrativa y sus compañeras e intentará reflexionar sobre ellas, mas no se centrará en las personas, en ella y sus compañeras que la cuidaron y la amaron en tiempos difíciles. De esta, manera se articula en Oblivion una invitación al diálogo como una forma de reflexionar sobre las acciones cometidas:

Vuelvo a casa despacio por la tristeza enredada en las palabras que escribo, por el silencio que sopla y que no se las lleva. Busco las palabras del perdón en el viento. Y estoy hablando de perdonarnos nosotros, vamos a aclarar. De oírnos como si cada uno cada una de nosotras fuera esa nota preciosa, necesaria. Yuyo verde, palabra del regreso de un país imposible. Perdonar quiere decir creer. Ellas creyeron, cuando yo no creía en mí (2012: 64).

La invitación de Fabbri señala el deseo de escucha como una manera de centrarse, ya no en el dolor del pasado, sino volver de él y creer en el colectivo, es el acto de confianæa al que alude Ricoeur (2010) cuando señala que perdonar significa separar al sujeto de su acto y darle la capacidad de empezar de nuevo. El perdón es una facultad que no se realiza en la soledad, que 
requiere de otros para poder concretarse ${ }^{18}$, ya que uno mismo no puede cumplir dos roles a la vez (víctima y victimario). Por ello es que en Oblivion hay una invitación al colectivo, a responder a la necesidad del individuo de escucha y perdón.

La pluralidad, la idea de lo colectivo, vuelve a cobrar importancia en el presente como la tuvo en el pasado, donde la voz plural se erigía por sobre la individual:

[D]e ese nosotras es difícil despegarse. Aquel pasado, o la mayor parte de él, solo puedo formularlo desde esa primera persona del plural. En aquella época hablábamos así, en 'nosotras' y 'ellos', y no había que aclararle a nadie el significado de esas palabras (Fabbri, 2012: 22-23).

La importancia de la voz plural se establece en que funciona como un frente de identidad, cohesión y resistencia orientado a una lucha en común en cuyo espacio convive la solidaridad y los sufrimientos compartidos. Así, lo colectivo de la experiencia se opone a la individualidad y aislamiento que las dictaduras trataron de imponer y se establece como un espacio de compañía, de afectos compartidos, de exigencias asumidas.

Forcinito señala que en el testimonio, sobre todo el femenino ${ }^{19}$, lo colectivo "desorganiza la heroicidad individual", sin embargo, en Oblivion más que resaltar el carácter heroico de las acciones se busca reflexionar sobre la derrota y las responsabilidades compartidas como argumenta Blixen (2010):

[E]n lugar de la reconstrucción de la gesta heroica de la resistencia, desarman la moral del combatiente y salen de la situación de víctima. Se instalan en una mirada más abarcadora que hace preguntas sobre la condición humana y que busca de una manera nada complaciente comprender la responsabilidad personal en lo sucedido (2010: 6).

La idea de explicar y explicarse no tiene como objetivo sólo explicar el presente, sino también mirar hacia las consecuencias del futuro próximo en el que tendrán que enfrentarse a los cuestionamientos de las siguientes generaciones quienes:

Nos recuerdan que no ganamos, no olvidan que no pudimos. Valió la pena, preguntan o se preguntan. Valió el dolor, la soledad, la de ellos, nos preguntan. Y no podemos contestarles bobadas $[\ldots]$

Cómo puedo decirte sí, valió; lo harías de nuevo, nos preguntan, te arrepentís. Y ellos saben en verdad que no son ésas las preguntas. Una pregunta mía es ésta: ¿pudimos haber hecho en ese entonces algo diferente? No me refiero a los pasos concretos que dimos, seguramente muchos de ellos en falso (yo dije que no iba a hablar de política, pero digo: claro que dimos pasos en falso, claro que nos equivocamos). Me refiero a si erramos la

\footnotetext{
18 Ricoeur argumenta: "La facultad de perdón y la de promesa descansan en experiencias que nadie puede realizar en la soledad y que se fundan totalmente en la presencia del otro. Si el origen de estas dos facultades es inherente a la pluralidad, su esfera de ejercicio es eminentemente política” (2010: 633).

19 Dice Forcinito que "[] as diferencias entre los acercamientos testimoniales femeninos y masculinos han recibido consideración en las discusiones sobre la escritura testimonial latinoamericana, sobre todo en cuanto a la formación, en el testimonio femenino, de una narrativa colectiva que desorganiza la heroicidad individual de las narraciones masculinas (2012: 111).
} 
opción, eso me pregunto. Y creo que mi respuesta es no, que entonces no había otra, quiero decir no había otra buena, otra mejor, otra viable (Fabbri, 2012: 67-68).

De este modo, Fabbri intentará cuidadosamente entretejer en su discursivo testimonial un espacio en el que convivan la memoria, el duelo, el dolor, el olvido y el perdón como formas que den cabida a una posible "memoria feliz, memoria apaciguada, memoria reconciliada, como serían las figuras de la felicidad que nuestra memoria desea para nosotros mismos y para nuestros allegados" (Ricoeur, 2010: 646). El intento exigirá convivir repetidamente con el dolor del cuerpo, para que este diga, para que posibilite el recuerdo.

La circularidad del relato que inicia y concluye con la idea: "[t]engo que empezar por el final, tengo que inventar un final, aunque sea provisorio, para poder empezar" (2012: 108), da cuenta de la compleja posición en la que se encuentra la voz narrativa y de la dificultad al emprender la labor del recuerdo, tarea que evidencia que el sujeto que recuerda se encuentra constantemente yendo al pasado para traer al presente nuevos significados. El individuo se enfrentará a la labor de reconocimiento ${ }^{20}$ cada vez que intente comprender el pasado porque la memoria es una continua reconstrucción.

\section{REFLEXIÓN FINAL}

Es posible evidenciar en Oblivion el fuerte vínculo que establece la vOz narrativa entre los recuerdos y su propio cuerpo, un cuerpo que tuvo que asumir en el pasado una labor de resistencia y registro para sobrevivir y testimoniar en el presente. Es en el dolor de la carne y los líquidos del cuerpo a los que el "yo" se ancla para mantener su identidad, para reconocerse en el violento y degradante mundo del encierro y la represión. Serán las percepciones sensoriales las que propiciarán el vínculo entre el sujeto y su experiencia, ellas permitirán hablar a la voz narrativa silenciada por los efectos del trauma.

Para que la experiencia se haga palabra, Fabbri debe recorrer un largo camino que implique trabajar su memoria desde el presente. Las imágenes fragmentadas que logra rescatar de los dolores del cuerpo, posibilitarán hilvanar su propia historia, una historia que no refiere a los "hechos", sino a los silencios, los miedos y las soledades que registran los sensores del cuerpo. Por ello es que enfatiza en que la "memoria no es lo que pasó, son sus huellas", aludiendo a que el recuerdo no será absoluto, sino vestigios, rastros de un pasado anclados en el cuerpo. Serán las huellas que Fabbri necesitará dejar para la posterioridad.

Además de lo anterior, es interesante observar cómo el trabajo de memoria de la voz narrativa se sostiene en una paradoja que consiste en articular los conceptos de memoria y olvido. El olvido aquí será entendido como un espacio de "sanación" que buscará hablar del pasado desde la reflexión y no desde el resentimiento. Este espacio será destinado para discutir, no de la violencia estatal la que no será olvidada, sino de la violencia interna ejercida entre las mismas compañeras de militancia. Por este mismo hecho es que Fabbri establece las categorías de memoria y dolor, olvido y perdón, para enfatizar en que es necesario hablar del pasado desde el

\footnotetext{
20 Bergson define el reconocimiento como "el acto concreto por el que volvemos a aprehender el pasado en el presente" (cita en Ricoeur, 2010: 563).
} 
presente sin vivir anclados en su dolor, sino que realizando un continuo trabajo de interpretación y reflexión. Por ello invita a sus compañeras a conversar sobre las luchas y las derrotas del pasado para comprender el presente y sus efectos en el futuro.

La escritura testimonial tendrá un importante rol en este proceso de reconstrucción porque a través de ella el superviviente podrá narrar el trauma vinculado a todos los acontecimientos disruptivos que atentaron contra la continuidad de su vida. Por ello no es de extrañar que el testimonio de Fabbri se encuentre siempre construido por los fragmentos del pasado que busca explicar y que algunas veces se cierran a la mirada. Son estos claroscuros los que persistirán en su memoria y a los que el testimonio les destinará un espacio donde converger. 


\section{BIBLIOGRAFÍA}

Alzugarat, Alfredo (2007). Trincheras de papel. Dictadura y literatura carcelaria en Uruguay. Montevideo: Ediciones Trilce.

BLIXEN, Carina (2010). "Deber de memoria y derecho al olvido: testimonio y literatura a partir de la experiencia de la dictadura cívico-militar (1973-1985) en Uruguay". Actas de La mémoire et ses représentations esthétiques en Amérique Latine, Rennes. Consultado el 15/09/2017.

Buriano, Ana. "Derecho, trauma social y restitución. Sincronía y unicidad: el caso de Uruguay". Andamios 18 (2012): 89-116.

CASAÑA, Inés y Fornet, Jorge (eds.) (2004). Premio Casa de las Américas. Memoria (2000-2004). La Habana: Fondo Editorial Casa de las Américas.

DraPER, Susana. "Victimes du souvenir et de l'oubli". Témoigner. Entre histoire et mémoire 118 (2014): 121-127. DOI: 10.4000/temoigner.961. Consultado el 14/04/2019.

FABBRI, Edda (2012). Oblivion. Montevideo: Letraeñe.

FORCINITO, Ana (2012). Los umbrales del testimonio. Entre las narraciones de los sobrevivientes y las señas de la posdictadura. Madrid: Iberoamericana.

FOrCinito, Ana. "La voz visible. Un acercamiento al testimonio de ex presos políticos en Uruguay". Kamchatka. Revista de análisis cultural 6 (2015): 529-547. DOI: 10.7203/KAM. 6.6402. Consultado el 20/04/2018.

FORNÉ, Anna. "La autoficción testimonial: Oblivion de Edda Fabbri”. Telar. Revista del Instituto Interdisciplinario de Estudios Latinoamericanos 7-8 (2010): 63-75. Consultado el 06/04/2018.

FRIED, Gabriela. “Trauma social, memoria colectiva y paradojas de las políticas de Olvido en el Uruguay tras el terror de Estado (1973-1985): memoria generacional de la post-dictadura (1985-2015)". ILCEA 26 (2016): 1-23. DOI: 10.4000/ilcea.3938. Consultado el 06/05/2018.

GILIO, María Esther. "Entrevista a Silvia Bleichmar". Semanario Brecha, Montevideo, $31 / 05 / 2002$.

Hormilla, Hellen. "La memoria es un derecho, el olvido una capacidad. Entrevista con Edda Fabbri”. La Jiribilla. Revista Cubana de Cultura 613 (2013). Consultado el 21/11/2017.

JELIN, Elizabeth (2002). Los trabajos de la memoria. Madrid: Siglo XXI.

LORENTE, Nuria. "La memoria: un campo en disputa. Usos y desusos del pasado reciente uruguayo". Kamchatka. Revista de análisis cultural 8 (2016): 275-302. DOI: 10.7203/KAM. 8.9157. Consultado el 20/04/2018.

NiETO, Judith. "El deber de la memoria, la imposibilidad del olvido. Alcances ético-políticos". Reflexión politica 15 (2006): 80-92.

PERIS BLANES, Jaume (2005). La imposible voz: Memoria y representación de los campos de concentración en Chile: la posición del testigo. Santiago de Chile: Cuarto Propio. 
Peris BLANes, Jaume (2008). Historia del testimonio chileno. De las estrategias de denuncia a las políticas de memoria. Valencia: Quaderns de Filologia.

Peris Blanes, Jaume. "Literatura y testimonio: un debate". Puentes. Revista de crítica literaria y cultural 1 (2014): 10-17.

Ricoeur, Paul (1999). La lectura del tiempo pasado: memoria y olvido. Madrid: Arrecife-Universidad Autónoma de Madrid.

Ricoeur, Paul (2010). La memoria, la historia, el olvido. Madrid: Trotta.

RocA, Fanscesc (1998). "Trauma: tragedia y tiempo". Estudios Psicoanalíticos 4. Trauma y discurso. Málaga: Eolia: 77-87.

SALVI, Lucas. "El juramento y la historia. Sobre Oblivion de Edda Fabbri”. Lingue e Linguaggi 17 (2016): 245-260. DOI 10.1285/i22390359v17p245. Consultado el 31/05/2018.

SARTRE, Jean-Paul (1993). El ser y la nada. Ensayo de ontología fenomenológica. Buenos Aires: Editorial Losada.

StrejILEVICH, Nora (2006). El arte de no olvidar. Literatura testimonial en Chile, Argentina y Uruguay entre los 80 y los 90 . Buenos Aires: Catálogos. 